\title{
A matter of consciousness - Introducing Zora Neale Hurston and Katie G. Cannon
}

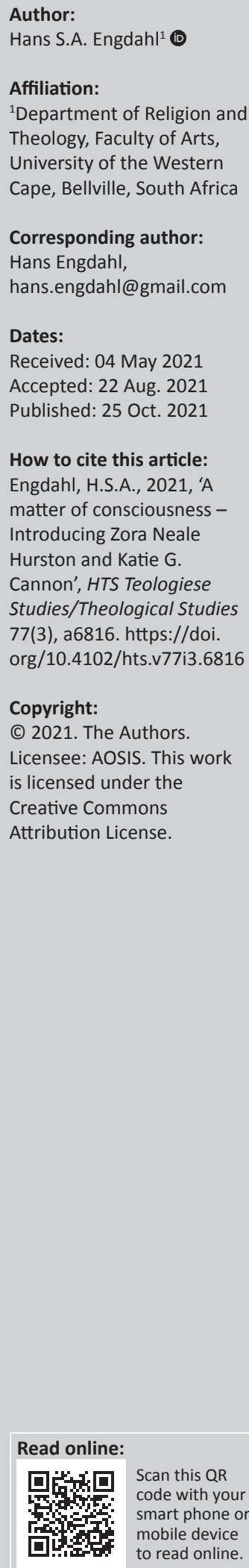

This article involves a close reading of two African American authors, Zora Neale Hurston, an acclaimed novelist and Katie Cannon, an influential theological ethicist. Texts from Steve Biko on black consciousness and from James Cone on liberation theology are used as methodological tools in trying to ascertain the degree to which Hurston and Cannon espouse a black (womanist) consciousness. A strong resonance of black consciousness will indeed be found in Hurston's and Cannon's texts. The conclusion drawn is that not only is there a resonance of black consciousness, but both writers also give proof of a black womanist consciousness that reveals new knowledge. Cannon's oeuvre also begs the question of epistemological privilege. In addition, an animated critique is registered between these women scholars and male colleagues, in the world of fiction (Richard Wright) and academia (white European males).

Contribution: This article demonstrates a link from South African black consciousness (Biko) to black womanist thinkers in the United States (Hurston and Cannon). A connection is also made between male, black liberation theology (Cone) and black womanist thinking, while expounding the womanist approach, liberated from (white) male dominance, on par with all others.

Keywords: black consciousness; womanist; fiction; epistemological privilege; appropriation.

\section{Introduction}

In this article, I contend that the black womanist (feminist) experience is indispensable as an insight to what is black consciousness and liberation theology, also sending a strong message to humanity at large. I further argue that in this womanist discourse, black consciousness and liberation theology are taken to a new level with new knowledge. Texts on Black Consciousness (Steve Biko) and Black Theology of Liberation (James Cone) are introduced. These texts from the 1960s and 1970s could certainly be deemed androcentric and patriarchal (Kobo 2019). One could also argue that to a certain point one should avoid being anachronistic. However, they are methodological tools in a further reading. Biko provides a definition of what could be black consciousness. Cone ties a Barthian stress on the unique revelation in Jesus Christ with uncompromised identification with the oppressed (blacks). He also admits to the need for black male theologians to give women free reign in black theological discourse.

The task then is to do a close reading of two African American women writers, namely Zora Neale Hurston, a novelist and Katie Cannon, a scholar in theological ethics. Both demonstrate an acute awareness of the legacy of black slavery and oppression. They complement each other, as Cannon draws inspiration from Hurston.

It will be discerned whether there are resonances of Biko's Black Consciousness and Cone's Black Theology of Liberation in the writings of these African American women.

While Cannon problematises Cone's stance, I argue that both Hurston and Cannon espouse a black womanist consciousness. The concluding discussion also takes up the notion of double consciousness' and the question of epistemological privilege.

\section{Black consciousness and black theology of liberation Steve Biko}

Steve Biko's relevance does not seem to disappear any time soon. During his last years, his context of being constantly harassed by the security police, until his untimely death, is all too easily

Note: Special Collection: New Landscapes in Identity: Theological, Ethical and Other Perspectives, sub-edited by John Klaasen (University of the Western Cape). 
forgotten. We are reminded of this stark context in the following quote. He is called in a defence of young black men who are on trial for their very thoughts. This was in 1976 (Woods [1978] 1979):

A group of nine young blacks were prosecuted in the Supreme Court for alleged subversion by intent. That is to say, in a sense, their thoughts were placed on trial. The State sought to establish that their philosophy, the Black Consciousness philosophy as enunciated by South African Students Organization and the Black People's Convention was a danger to public safety in that it was likely to lead to a mobilization of black opinion against the established white order in a manner calculated to cause 'radical confrontation'. (p. 161)

Thoughts that could be identified with the Black Consciousness philosophy had now become a major crime in itself deemed as terrorism (Woods [1978] 1979:225). Biko (1978) had this to say:

\begin{abstract}
Apartheid is obviously evil... All in all, the black man has become a shell, a shadow of man, completely defeated, drowning in his own misery, a slave, an ox bearing the yoke of oppression with sheepish timidity... [T] he only vehicle for change are these people who have lost their personality. The first step therefore is to make the black man come to himself, to pump back life into his empty shell, to infuse him with pride and dignity, to remind him of his complicity in the crime of allowing himself to be misused and therefore letting evil reign supreme in the country of his birth. This is what we mean by an inward-looking process. This is the definition of 'Black Consciousness'. (p. 29, 31)
\end{abstract}

\section{James Cone}

James Cone visited Johannesburg in 1969 and gave lectures there. Outlining his Black Theology and Black Power, he also influenced young blacks who eventually became prominent in the Black Consciousness Movement. ${ }^{1}$ Thus, Cone was called to inspire this movement at this early stage. The underpinnings of a Black Theology of Liberation Cone phrases like this (Cone 1975b):

$[T]$ here can be no knowledge of Jesus independent of the history and culture of the oppressed... The convergence of Jesus Christ and the black experience is the meaning of the Incarnation. Because God became man in Jesus Christ, he disclosed the divine will to be with humanity in our wretchedness. And because we blacks accept his presence in Jesus as the true definition of our humanity, blackness and divinity are dialectically bound together as one reality. (p. 34f.)

The nearly total male domination in Black Theology was something that Cone eventually and very forthrightly tried to deal with. But there were excuses. He mentioned two possible obstacles to dealing with black women's predicaments. Firstly, feminism was perceived as driven by white women and as a black person from the south, he shivered at the very thought (Cone 1986):

As a Southern black, I could not forget the role that white women played in the lynching of black men... I can remember the fear that many black men experienced while in the vicinity of a white

1.As far as I have been able to ascertain, there is no evidence that he met with Biko at this time. woman, because her word alone could get a person lynched... (p. 116)

Secondly (Cone 1986), there was at least a perception that: '[m]any black women contended that their silence on sexism did not mean that it was absent in the black community, but only that they did not wish to divide black men and women in the struggle against racism' (p. 117f.).

The following quote I think shows that Cone eventually did understand the full implications of the role of women in the struggle for freedom, dignity and justice (Cone 1986):

$[B]$ lack women are seeking to combine the issues of race, sex and class, because they are affected deeply by each. It is too early to say what the exact characteristics of black feminist theology will be because it is still in the process of development. What is certain is that it will not be mere duplication of the black theology of black male theologians or of the feminist theology of white females. (p. 119f.)

This was printed in My Soul Looks Back ([1982] 1986). Here is at least a link to what now follows: a presentation of two African American women.

\section{Two African American writers: Zora Neale Hurston and Katie Cannon Zora Neale Hurston (1901-1960)}

Zora Neale Hurston ${ }^{2}$ was 'born and grew up in the first incorporated all-Black town in the United States (Eatonville, Florida... [today part of Orlando])' (Cannon 1988:99). Her mother died when she was only 9 years old. She soon had to look after herself. As if the dying mother was aware of this state of affairs soon becoming a reality, she encouraged her daughter Zora to stay strong and continued to tell her that loving somebody else more than herself would get her killed very soon. Some of these things she wouldn't understand as a 9 year old, but eventually she would (Sporre 2015).

As a child she had the luxury of a big house and a huge garden, but not so after the death of her mother (Cannon 1988:99f.).

Eventually, she took on this very world, well aware of her gift of expressing herself in writing. What made her famous were her novels. The 1930s is the decade of a stunning production: Jonah's Gourd Vine (1971), Their Eyes Were Watching God (1978), Moses, Man of the Mountain (1978). No other African American woman had achieved anything like this at this time. And yet she was not readily accepted into the hall of fame of the writers of the male dominated Haarlem Renaissance (Cannon 1988:128ff.).

The sad thing is that she was not able to sustain her achievements. Her life was, financially speaking, quite precarious. Eventually, she returned to Florida, where she

2.1 am here to rely on Cannon who did her doctorate on Hurston. This could be problematic had the task been to compare the two, but this essay is about problematic had the task been to compare the two, but this essay is about
identifying common trends regarding black consciousness and then dependency need not be a liability but rather an asset. 
struggled to survive, casually contributing articles to various magazines. She died in 1960 from 'hypertensive heart disease', when not yet 60 years old (Cannon 1988:113, 116).

One novel, one essay: Their Eyes Were Watching God is Hurston's most popular work. The protagonist Janie Crawford is seeking a happy marriage, seemingly in vain. An important part of the book is her conversation with the grandmother, Nanny Crawford, 'a freed slave woman who understood marriage as the way to escape poverty and abuse, as a way to avoid the traditional fate of Black women' (Cannon 1988:132). Nanny tells her story of violence and abuse at the hands of the white slaveowner. She runs away with her illegitimate child and manages to escape. To her life is now to have what she always missed, enough possessions and a secure life.

But after Emancipation, the grandmother talked about quiet grace as a way of allowing oneself to dream and come up with aspirations. She dreamt about being given a chance 'to preach a great sermon about colored women sitting on high, but there wasn't no pulpit for me' (Hurston [1937] 1978:31f. in Cannon 1988:133).

For the first time, in her third marriage, Janie Crawford finds solace, a relationship with an 18 years younger man, a relationship free from domestic violence. 'Janie becomes larger than her world, embracing the horizon as the limit, and throwing off the shackles of womanhood and society' (Howard 1976:108, in Cannon 1988:135).

What the book dispels is the life of a black woman totally beyond the constraints of oppression:

$[H]$ ere we may learn Black possibilities of ourselves if we could ever escape the hateful and alien context that has so deeply disturbed and mutilated our rightful efflorescence - as people. (Jordan 1976:6, in Cannon 1988:136)

If one wanted to find an example of a black American woman who is at ease with being black and yet being convinced that she is an authentic part of greater humankind, one should read Hurston's essay: 'How it feels to be colored me'. It became overtly clear that this woman was seeing herself as a world citizen:

[A]t certain times, I have no race, I am me. When I set my hat at a certain angle and saunter down Seventh Avenue, Harlem City, feeling as snooty as the lions in front of the Forty-Second Street Library, for instance... The cosmic Zora emerges. I belong to no race nor time, I am the eternal feminine with its string of beads. I have no separate feeling about being an American citizen and coloured. I am merely a fragment of the Great Soul that surges within the boundaries. My country, right or wrong. (Hurston 1928)

So, what more could you say than this: 'Sometimes, I feel discriminated against, but it does not make me angry. It merely astonishes me. How can any deny themselves the pleasure of my company! It's beyond me' (Hurston 1928).
The concept of 'unshouted courage': There is a concept that is discernible in Hurston's fiction, namely 'unshouted courage', 'a virtue evolving from the forced responsibility of Black women' (Cannon 1988:143). There are instances where there is certainly a shout, but this shout has to take different forms, at least for a time (and this time has for some a duration of hundreds of years) (Cannon 1988):

'[U]nshouted courage' is the quality of steadfastness, akin to fortitude, in the face of formidable oppression... [I] tinvolves the ability to 'hold on to life' against major oppositions. It is the incentive to facilitate change, to chip away the oppressive structures, bit by bit, to celebrate and rename their experiences in empowering ways. (p. 144)

Encountering the enormity of black slavery is very humbling. It seems that Zora Neale Hurston reflected this 'unshouted courage' well:

In her essays, the inference of 'unshouted courage' continued to be derived from its prominence in the Black community. Walker (ed. 1979:151), in introducing Hurston's nonfiction, asserts that the fundamental thesis that Hurston embodied and exhibited in her essays was that one 'must struggle every minute of life to affirm black people's right to a healthy existence'. This idea concurs with the understanding of courage in Paul Tillich's work (1952:3, 178-190). Tillich says that courage is an ethical act when humans affirm their own being in spite of those elements in their existence which conflict with their essential self-affirmation. (Cannon 1988:146f.)

Black womanist ${ }^{3}$ consciousness: One could say that Hurston identified with the black community. The greatness of her work, as I see it, lies in this very ability to concentrate fully on this legacy: a history rooted in slavery, rich in artistic articulation, of those people who emerged from unbearable conditions, having been kept together by women.

Hurston was not tempted to do what others did (Cannon 1988):

While Hurston's other colleagues were expropriating white antagonism as the cause for the poverty of the masses who supposedly languished in despair, anger and defeatism, Hurston was trekking through the South collecting the Black classics in music, art, dance and literature with hopes of eventually correcting dominant misconceptions about the quality of life in the Black context. (p. 108)

A further sign that Hurston took the striving towards what would be called a Black Womanist Consciousness seriously is her opposition to integration. She was heavily criticised for this (Cannon 1988):

$[W]$ hen most Black leaders were organizing around integration as a goal, Zora Hurston was a lone frontrunner who saw the implementation of integration as an affront and threat to the Black community. (p. 110)

And she has this to say about forced school integration (Cannon 1988:110; Hurston 1955; Washington 1972):

3.The term is used here denoting this special consciousness despite it becoming a technical term only after her death. 
[T] he whole matter revolves around the self-respect of my people. How much satisfaction can I get from a court order for somebody to associate with me who does not wish me near them... It is a contradiction in terms to scream race pride and equality while at the same time spurning Negro teachers and self-associations.

Yet Hurston 'believed in the principle of an integrated society', but not in a situation where the white majority was the norm. In the end, '[h]er work was an affirmation of the Black race as one of the great human races, inferior to none in its accomplishments and in its ability' (Cannon 1988:111; Hurston 1945:45)

Finally, there is a reason for commenting on Richard Wright's critique of Hurston (Cannon 1988:122; Wright 1937) here. His review of Hurston's Their Eyes Were Watching God has become famous for its dismissiveness. He says, what is missing is 'a basic idea or theme that lends itself to significant interpretation. Miss Hurston seems to have no desire whatever to move in the direction of serious fiction'. He furthermore deems the novel as useful for whites' entertainment in line with what minstrels would have on offer: 'Miss Hurston voluntarily continues in her novel the tradition which was forced upon the Negro in the theatre, that is, the minstrel technique that makes the "white folks" laugh".

Richard Wright who at this time was becoming world renowned for novels like Native Son (1940) and The Outsider (1953), here more or less writes off Hurston's novel and this had a devastating effect what regards her further career. Richard Wright has, rightly or wrongly been portrayed as a misogynist (Gilroy [1993] 2003:146ff.).

Two further comments have to be made. Firstly, Wright has not understood Hurston at all. As already commented upon, this novel is an African American woman's trajectory all the way from chattel slavery to freedom, also personal freedom, under circumstances where she is able to please herself. Talk about the lack of 'basic idea or theme'!

Secondly, Hurston and Wright could be seen as being at opposite ends of things. While Hurston aims at solidifying her people and their immense gifts just where they are, in her fiction, Wright is at the other end. Having made fame, he rejects the American society, also in terms of ideology (he becomes a communist for some years), takes leave for Europe and spends his last 13 years in Paris. Even he is true to his ultimate ideals: his writings (even though this is much less known) taken as a whole took on global and cosmopolitical dimensions (Gilroy [1993] 2003:146ff.).

\section{Katie Cannon (1950-2018)}

Katie Cannon grew up in Kannapolis, North Carolina. The slave background is a given. The Cannons made out a whole clan as they had been sharecroppers in the area for a long time. Her mother stemmed from people involved in work as house servants. She now married into this Cannon family (Cannon 1995:162).
The mother, Corine Emmanuelette Lytle Cannon, meant a lot to her. Cannon (1995):

[S]he was named for her father Emmanuel... She loved her mother. Grandma died in her arms. She always wanted to be schoolteacher or a businesswoman. She had so many dreams. When she realised that she couldn't fulfil her dreams, she just gave those dreams to us... I was never ashamed that my mother was a domestic because everybody else's mother was a domestic, if they worked at all. So, I knew I'd grow up to be a domestic. (p. 167f.)

She continues:

So I'd walk down to Mrs. Chapman's house and clean up her house and take care of her four kids. One of the daughters was as old as I was, maybe twelve, named Blondie. They would sit around and watch TV and play games, and they didn't think anything of the fact that I was cleaning. (p. 170) (cf. Magona [1991] 2008)

Black consciousness reached a high pitch when as a student Katie Cannon experienced the murder of Martin Luther King (Lawrence-Lightfoot 1994):

The rage over the war (Vietnam), the death of their (black) men and the rage over King, the death of The Man, combined to create a black rage hotter than any this country had ever known... She (also) became a devotee of Malcolm X. (p. 63f.)

Black feminist consciousness: Cannon prefers giving her people's history, a history of slavery and the slow, if ever, emancipation therefrom. It may be the best way of actualising the stark consciousness that is there. People carry their history with them. She gives glimpses of three phases, that of the actual slavery, the post-civil war reconstruction and Jim Crow era, and 20th century railroad tracking to the north and, to make sure, continued segregation. The whole story is emerging with the black church as the backbone.

It is a church that is from its inception marked out as a black or African church (Lincoln 1973:vii-viii, in Cannon 1995:47f.):

The blacks brought their religion with them. After a time they accepted the white man's religion, but they have not always expressed it in the white man's way... The black religious experience is something more than a black patina on a white happening. It is a unique response to a historical occurrence that can never be replicated for any people in America... The faith assertion of the Black church encouraged slaves to reject any teachings that attempted to reconcile slavery with the gospel of Jesus Christ.

Ingenuity was these women's hallmark:

The slave woman's religious consciousness provided her with irrepressible talent in humanizing her environment. Having only from midnight to daybreak to provide love and affection for her own offspring, the Black woman returned at night with leftovers, throwaways, discarded shells of the White slaveowner's rubbish to the small, crude, squalid dwelling where she made a home for her family. Often, she took into her quarters Black children whose parents had been sold away from 
them or they from their parents with the full knowledge that she could expect to have her own offspring with her for a few years, at the most. (p. 48f.)

Cannon (Cannon 1995; Walker 1983) also suggests that it may be more accurate to identify a Black womanist consciousness rather than a Black feminist consciousness. She refers to Alice Walker, who also says that 'womanist is to feminist as purple is to lavender' (p. 174; xi-xii).

Doing black womanist ethics and theology: In Katie's Canon chapter 10 (122-128), Cannon tries to clarify the role race and gender may have in a discourse of Black liberation ethic/ theology. It is a question of going with the 'canonical boys' or with the 'noncanonical other'.

It is about 'hitting a straight lick with a crooked stick' (p. 122). ${ }^{4}$ Joining the canonical boys could mean succumbing to the temptation 'of mastering only the historically specified perspective of the Euro-American masculine preserve' (p. 123).

The canonical boys, that is, 'membership in this highly complex fraternity means investigation of abstract metatheory, traditional philosophical thought, and the established canon of ethical inquiry with supposedly calm and detached objectivity' (p. 122f.). In such a discourse, '[u]niversality does not include the Black female experience' (p. 123).

And, as if her case were not clear enough, Cannon (1995) repeated:

[T]he moral agency of Black women must be understood on their own terms rather than being judged by essentially abstract external ideological norms and squeezed into categories and systems that consider White men the measure of significance. Lives of Black women cannot be fully comprehended using analytical categories derived from White/male experience. Oftentimes, such concepts overtly sustain a hierarchy of White supremacy, patriarchy and exploitative power. (p. 124)

So what about the noncanonical other? Cannon (1995) gives a few important hints.

[The (Black) womanist scholar] insists that new questions guide the research so that Black women's moral wisdom can provide the answers. In essence, she seeks to determine why and how Black women actively negotiate their lives in a web of oppression. ... The intersection of race, sex and class gives womanist scholars a different ethical orientation with a different ideological perspective. ... To demystify large and obscure ideological relations, social theories, and, indeed, the heinous socio-political reality of tridimensional oppression is a moral act. To do ethics inside out and back again is the womanist norm. (p. 125)

4.This is Zora Hurston's expression. The criticism that she had to endure from the white establishment or from male fiction writers (Richard Wright etc.) she fought with the crooked stick of the immense fund of Black women's experiences and with the crooked stick of the immense fund of Black women's experiences and
traditions. That Cannon 'borrows' from the literary work of Hurston proves that the literary language adds to the work of Cannon as an ethicist. In turn, as demonstrated literary language adds to the work of Cannon as an ethicist. In turn, as demonstrated
above, Cannon as an ethicist systematises the work of Hurston - it is like a mutual relationship between their work.
It may well be that Cannon here is announcing a sea change:

$[W]$ hether the discipline of ethics has almost completely neglected Black women (as in White male scholarship) or treated them as incidental to central issues (as in Black male scholarship) or considered gender as the important factor for research (as in White feminist scholarship), the cumulative effect of womanist scholarship is that it moves us towards a fundamental reconceptualization of all ethics with the experience of Black women at center stage. (p. 128)

Chapter 11 (129-135) is about appropriation and reciprocity. In how far is it legitimate to appropriate ideas, subject matter, method etc. from elsewhere? It could also be about a centuries' long appropriation. Cannon mentions two instances, black theology's dependence on white Eurocentric theology and black womanist dependence on white feminist discourse.

Cannon (1995) quotes Cecil W. Cone (an elder brother of James Cone) (1975a) on black theology's dependence on white theology:

$[B]$ ecause theology, like other fields of western intellectual activity, was developed by white people, it ignored black religion. It is not surprising, therefore, that a large part of its methods and results are inappropriate for black theologians. (p. 129; 118f.)

His conclusion is simply 'that contemporary writers of Black theology cannot probe the depth and scope of Black religion if they use the academic tools of White theologians' (Cannon 1995:130).

The other instance of appropriation has to do with feminist discourse (Cannon 1995; Sanders 1989). At a Womanist Roundtable Discussion, Sanders (1989) stated the following referring to current womanist scholarship:

$[T]$ he fact that almost all of their footnotes are derived from the writings of black women sends the important signal that we are appreciating, analyzing and appropriating our own sources and also those of black men, without appealing for the most part to white sources for sanction and approval of what we ourselves have said... To see black women embracing and engaging our material is a celebration in itself. (p. 130; p. 111)

This blunt admission of the need for being clear cut in terms of whom you are profiting from came as a shock to Cannon (p. 130f.). What about her making use of white feminists like Beverly W. Harrison and Elisabeth Schüssler Fiorenza in order to be able to substantiate her theoretical arguments?

Leaving the idea of a common humanity behind, things become fiercely incompatible and punitive. She thus exclaimed:

[E]very reflective and well-intentioned African American scholar who is consciously concerned with 'the liberation of a whole people' must work to eradicate the criterion of legitimacy that implicitly presumes an absolute incompatibility between 
womanist critical scholarship and White feminist liberationist sources. (p. 131)

Being under pressure to choose between racial identity and womanhood, Cannon (1995) is also aware of the fact that:

[E]ither we are Blacks or we are women. Despite womanist scholar's best efforts in arguing that this is a conceptual impossibility because we embody both realities as Black women, the full force of the punitive and damaging effects of binary categories remains intact. (p. 131)

In the end, Cannon's view seems to be that reciprocity is a mutually agreed upon appropriation. Here, we could also sound reservations regarding the Cone brothers, to the extent that their theologies would close the door to any other insights than those of blacks.

\section{Concluding discussion Black consciousness and double consciousness}

The notion of double consciousness was formulated by Du Bois (1903) more than 100 years ago. Ever since, there has been a discussion on how this notion should be understood. Having grown up in a predominantly white neighbourhood in northern USA, he saw two distinct worlds in operation:

It is a peculiar sensation, this double-consciousness, this sense of always looking at one's self through the eyes of others, of measuring one's soul by the tape of a world that looks on in amused contempt and pity. One ever feels his twoness - an American, a Negro; two souls, two thoughts, two unreconciled strivings; two warring ideals in one dark body, whose dogged strength alone keeps it from being torn asunder. (Du Bois 1903:3)

As was the case with Richard Wright, Du Bois saw this tension as an unresolved matter and would eventually leave his native country. He does not argue for a circumstance under which such a tension would be resolved.

Nor does Gilroy ([1993] 2003), who writes at the end of the same 20th century: 'Striving to be both European and black requires some specific forms of double consciousness' (p. 1). In his epoch-making work, Gilroy (p. 4) plays with the two words 'roots' and 'routes', clearly opting for the latter, making the black Atlantic the 'chronotope', a term signifying a specific time as well as place. The long history of slave trade is linked with constant motion between the continents up to this moment. As a black, Briton Gilroy is (bound) to conclude that there is no single consciousness on offer, at best a mutual acceptance of hybridity. Whether this is a problem or a benefit is just the contentious point.

In South Africa, Du Bois is well understood, but then in terms of an insoluble African-American context (Eze 2011:225, in Vellem 2015:656): 'Double consciousness, according to Emmanuel Eze, is a theory that articulates "a psychology of the racialized black self" against the true self-consciousness of blackness'.

Colonialism has effected this bifurcation:
[T] he historical division of amaXhosa, surely even amaZulu, Batswana, Basotho and others, is not only a physical, territorial division that speaks to the antics of colonial 'divide and rule', but also bodily and psychological divisions following $\mathrm{Du}$ Bois, and we could include Franz Fanon and Steve Biko. (Vellem 2015:656)

Would double consciousness in the end have to be understood as the black person running away from the black self? South African Vuyani Vellem (2015) left no room for doubt and as a counterpart to the Black church in the USA, he said:

[I]mportantly, and painfully so, this is a narrative of the propensity of the black flight from the black self. Black ecclesiology does not and cannot be a product of a bifurcated system of knowledge, categories and concepts. (p. 656)

It is about one, undivided black consciousness. It is not a nationalism, nor ethnocentrism. It is a movement, and it is open-ended, signifying freedom. There is no indication that Hurston and Cannon saw double consciousness as a way forward.

\section{Black womanist consciousness}

As was envisaged in the introduction, the texts by Biko and Cone are seen as methodological tools to be used in reading Hurston and Cannon.

In the introduction, I expressed opinions about possible resonances of black consciousness, as a search for one's humanness as Biko construed it, in the writings of the two African Americans Zora Hurston and Katie Cannon. My conclusion here is that it is more than mere resonances. What I have found is nothing less than very prime examples of black (womanist) consciousness. And this goes for Hurston as well as Cannon.

Zora Hurston's whole oeuvre is one whole demonstration of the importance of creating a black self-awareness at all costs. All novels of hers, except one, have a black cast.

The notion of 'unshouted courage' underwrites black women's determination to endure at all costs. It is born out of a situation of oppression where there is no obvious prospect of change for the better; but there is courage, an unbound courage.

So, there is a black womanist consciousness expressed in these texts. As I say above, the greatness of her work 'lies in the very ability to concentrate fully on this legacy'.

She is also consistent, well in line with Black Consciousness thinking in South Africa, when it comes to integration on the terms of the majority. She saw it as a threat to the black community.

As with Biko, such a view does not in any way negate the fact and possibility of an integrated society. There should be such a vision of a new humanity (p. 108). 
The confrontation with Richard Wright gives a very similar result. Hurston failed in her career, broke down and returned to her home state Florida, but she stayed faithfully with her ideal of enhancing her people. Wright became famous but in faraway Europe.

When it comes to Katie Cannon, similar things could be said. Her biography as well as her history of black women speaks the same language. In fact, her very concentrated historical account of black women from the 17th century until the mid1950s deals with one thing more than anything else: this is an account of black womanist consciousness. Here is the black woman's 'unshouted courage' in all its stark reality. This is but one example of how Cannon has systematised Hurston's implied ethics.

In addition, unlike Hurston, Cannon puts a very strong emphasis on the role of the church through all these years of oppression. Here I want to actualise James Cone's emphasis of black theology of liberation. His views seem to be much on par with Cannon here. It is a church that envisions liberation.

Biko underlined this internal process of black consciousness:

$[T]$ he only vehicle for change are these people who have lost their personality. The first step, therefore, is to make the black man come to himself, to pump back life into his empty shell, to infuse him with pride and dignity. (p. 2)

It is to me quite clear that Hurston and Cannon operated along these same lines. Their lives were a struggle that had not come to a close.

Cannon also brings in new perspectives. Three things: she prefers the term 'womanist', she is low on visions and she does not capitalise on possible epistemological privileges.

Using 'womanist' rather than 'feminist', Cannon makes use of a trope from Alice Walker preferring the deeper shade of purple to lighter blue-purple lavender. She has reservations against integrating 'the womanist' either into a feminist or black liberation theological discourse (Sporre 1999:485).

When it comes to visions of the future, we are rather at a loss. At best, it would be about a continued struggle for justice, the outcome of which is nothing but clear. Rather what is striking is the value that is given to tradition in any attempt to face a future, and 'this deeper-than-surface knowledge of and fondness for the verbal tradition is a truth that is shared by the majority of Black women writers' (Cannon 1995:65).

Mary Helen Washington supports her case: ‘This remembrance of things past is not simply self-indulgent nostalgia. It is essential to her vision to establish connections with the values that nourish and strengthen her' (Washington 1979b:95f.). Karin Sporre, who deals with Cannon's texts extensively, looks at the visionary side of Cannon in this way:
[I]t stands out that Cannon's texts are visionary in this way: they talk about the past, seeking moral insights of black women... in order to restore dignity of black women of our time. (Sporre 1999:241)

This way of looking back should not be seen as not being concerned with the future. The African American legacy, being what it is now, even into the 21st century, remains a repository of wisdom to be drawn for days to come. I believe this legacy is firmly within the wider African tradition where wisdom is sought in the past (Mbiti [1969] 1989).

\section{Epistemological privilege and taking things to a new level}

Epistemological privilege is the third issue now to be addressed and it has been widely discussed. There are three factors of relevance, the first two of which should be selfevident. The articulation of women's experiences has yielded social knowledge. This knowledge must, in a historical perspective, be seen as new knowledge. From a scientific point of view, massive new knowledge has been produced during the last, say, 40 years (Sporre 1999:140).

The third factor is the contested one. The knowledge gained by women and now articulated, is that knowledge privileged, and if so, in what sense? Some might claim that here is a truth claim that is better or of higher value than other knowledge. It then becomes a truth claim that is non-negotiable. Sporre (1999) said: 'Formulated in such a way I would take exception from such an epistemological privilege' (p. 140). Now over to Cannon; she has a lot speaking for her in terms of deep, hard won insights. She says this about such knowledge (Cannon; Lawrence-Lightfoot 1994):

$[Y]$ ou know where the minefields are... there is wisdom... You are in touch with the ancestors... and it is from the gut, not rationally figured out. Black women have to use this all the time, of course, the creativity is still there, but we are not fools... we call it the 'epistemological privileges of the oppressed'. How do you tap that wisdom - name it, mine it, pass it on to the next generation? (p. 11; p. 59f.)

As to whether Cannon would have seen her and other black womanists' insights as an epistemological privilege of a higher order or as an indisputable truth claim, the following could be said. With a few exceptions, black women have never been able to tell their stories:

$[T]$ he privilege to reflect in order to prevail beyond survival is not granted to them, so their epistemological privilege either lies dormant, in some kind of state of denial or self-delusion, or it is acted out in ways that get black women beaten up, incarcerated, mutilated. How to channel this wisdom is the essential concern of the ongoing survival of women of colour. (Cannon et al. 1985:41, in Sporre 1999:234)

It may well be that Cannon does not want to make use of an epistemological privilege as just described. She is firm in her argument about new knowledge provided by black women but not in order to substitute what is already there. Perhaps, 
the following quote gives us guidance, and the context is her critique of the white male academic establishment. She makes clear that her other criteria are decisive in her research, but not in isolation from the establishment, rather it is paramount that '[t]he liberation ethicist works both within and outside the guild' (Cannon 1995:124). There is no trace of superiority or claim of knowing better. What impresses me is this unassuming but robust and indispensable insight, not at the expense of others, but on par with all others.

This brief encounter with Hurston and Cannon shows that things are taken to a new level. New knowledge that is inherent in the black womanist experience speaks to the fruitfulness and necessity of these kinds of womanist perspectives and cannot be dispensed with. It sends a message to the wider community of black consciousness and to all.

Suffice it to be concluded that henceforth any serious study of human relations would have to take into account Black womanist discourse and consciousness.

\section{Acknowledgements Competing interests}

The author declares that he has no financial or personal relationships that may have inappropriately influenced him in writing this article.

\section{Author's contributions}

H.S.A.E. is the sole author of this article.

\section{Ethical considerations}

This article followed all ethical standards for research without direct contact with human or animal subjects.

\section{Funding information}

This research received no specific grant from any funding agency in the public, commercial, or not-for-profit sectors.

\section{Data availability}

Data sharing is not applicable to this article as no new data were created or analysed in this study.

\section{Disclaimer}

The views and opinions expressed in this article are those of the author and do not necessarily reflect the official policy or position of any affiliated agency of the author.

\section{References}

Biko, S., 1978, I write what I like, The Bowerdean Press, London.

Cannon, K.G., 1988, Black womanist ethics, Scholars Press, Atlanta, GA.

Cannon, K.G., 1995, Katie's Canon. Womanism and the soul of the black community, Continuum, New York, NY.

Cannon, K.G., Harrison, B.W., Heyward, C., Isasi-Diaz, A.M., Johnson, B.B., Pellauer, M.D., 1985, God's fierce whimsy. Christian feminism and theological education, Pilgrim Press, Cleveland, $\mathrm{OH}$.

Cone, C.W., 1975a, The identity crisis in black theology, African Methodist Episcopal Church, Nashville, TN.

Cone, J., 1975b, God of the oppressed, Seabury Press, Minneapolis, MN.

Cone, J., [1982] 1986, My soul looks back, Orbis Books, Maryknoll, New York, NY.

Du Bois, W.E.B., [1903] 2003, Souls of black folk, A. C. McClurg \& Co, Chicago, IL.

Eze, E., 2011, 'Double consciousness and the democratic ideal', in J.T. Levy \& M.I. Young (eds.), Colonialism and its legacies, chapter 11, Lexington Books, MD.

Gilroy, P., [1903] 2003, The Black Atlantic. Modernity and double consciousness, Harvard University Press, Cambridge, MA.

Howard, L.P., 1976, Zora Neale Hurston: A non-revolutionary black artist, University of New Mexico, Albuquerque, NM.

Hurston, Z.N., 1928, 'How it feels to be colored me', in The World Tomorrow, May.

Hurston, Z.N., 1945, 'Crazy for democracy,' Negro Digest, December, pp. 45-48.

Hurston, Z.N., 1955, Orlando sentinel, 11 August.

Hurston, Z.N., [1937] 1978, Their eyes were watching God, Lippincott Co., Philadelphia, PA.

Jordan, J., 1976, 'On Richard Wright and Zora Neale Hurston: Notes toward a balancing of love and hatred', Black World, April.

Kobo, F., 2019, 'Womanism and black anthropology: In memory of James Cone', Journal of Theology of Southern Africa 162\&163, 82-100.

Lawrence-Lightfoot, S., 1994, I've known rivers. Lives of loss and liberation, Penguin Books, New York, NY.

Lincoln, C.E., 1973, foreword to William R. Jones, Is God a White Racist? Doubleday \& Co., Anchor Books, Garden City, New York, NY, pp. vii-viii.

Magona, S., [1991] 2008, Living, loving, and lying awake at night, David Philip Publishers, Claremont, Cape Town.

Mbiti, J.S., [1969] 1989, African religions and philosophy, Heinemann, London.

Sanders, C.J., 1989, 'Christian ethics and theology in womanist perspective', Journal of Feminist Studies in Religion 5(2), 83-112.

Sporre, K., 1999, Först när vi får ansikten. Ett flerkulturellt samtal om feminism, etik och teologi, Atlas Akademi, Stockholm.

Sporre, K., 2015, In search of human dignity. Essays in theology, ethics \& education, Sun Press, Stellenbosch.

Tillich, P., 1952, The courage to be, Yale University Press, New Haven, CT.

Vellem, V., 2015, 'Black ecclesiology. Uprising faith praxis for the blackness of humanity', The Ecumenical Review 67(4), 651-663.

Walker, A. (ed.), 1979, I love myself when I am laughing. A Zora Neale Hurston Reader, The Feminist Press, Old Westbury, New York, NY.

Walker, A., 1983, In search of our mothers' gardens: Womanist Prose, pp. xi-xii, Harcourt Brace Jovanovich, New York, NY.

Washington, M.H., 1972, 'The black woman's search for identity, Zora Neale Hurston's work', Black World 21(10), 68-75.

Washington, M.H., 1979a, 'Introduction', A Zora Neale Hurston Reader, The Feminist Press, Old Westbury, New York, NY.

Washington, M.H., 1979b, Midnight birds: Stories of contemporary black women writers, Double Day \& Co., Garden City, New York, NY.

Woods, D., [1978] 1979, Biko, Penguin Books, Harmondsworth, Middlesex.

Wright, R., 1937, 'Between laughter and tears', New Masses, October. 